\title{
Tuberculosis: limitations and strengths of Directly Observed Treatment Short-Course ${ }^{1}$
}

\author{
Elisangela Martins de Queiroz ${ }^{2}$ \\ Mónica Cecilia De-La-Torre-Ugarte-Guanilo ${ }^{3}$ \\ Kuitéria Ribeiro Ferreira ${ }^{2}$ \\ Maria Rita Bertolozzi ${ }^{4}$
}

This study analyzed the limitations and strengths of the Directly Observed Treatment ShortCourse (DOTS) for tuberculosis from the perspective of patients and healthcare providers in a Technical Health Supervision unit in the city of São Paulo, SP, Brazil. Four patients and 17 healthcare providers from nine Primary Care Units were interviewed from April to June 2006, after signing free and informed consent forms. The reports were decoded according to the speech analysis technique. The Theory of the Social Determination of the Health-Disease Process was adopted as the theoretical framework. The strengths were: establishment of bonds between healthcare providers and patients and the introduction of incentives, which promotes treatment adherence. Limitations included: restricted involvement of DOTS' healthcare providers and reconciling patients' working hours with supervision. Treatment adherence goes beyond the biological sphere and healthcare providers should acknowledge patients' needs that go beyond the supervision of medication taken.

Descriptors: Tuberculosis; Directly Observed Therapy; Patient Compliance; Nursing.

\footnotetext{
${ }^{1}$ Supported by Fundação de Amparo à Pesquisa do Estado de São Paulo (FAPESP), process \# 2009/12977-3.

2 Master's students, Escola de Enfermagem, Universidade de São Paulo, Brazil.

${ }^{3}$ Doctoral student, Escola de Enfermagem, Universidade de São Paulo, Brazil.

${ }^{4} \mathrm{PhD}$, Associate Professor, Escola de Enfermagem, Universidade de São Paulo, Brazil.
}

Corresponding Author: Maria Rita Bertolozzi Universidade de São Paulo. Escola de Enfermagem

Av. Dr. Enéas de Carvalho Aguiar, 419

Bairro: Cerqueira César

CEP: 05403-000, São Paulo, SP, Brasil

E-mail: mrbertol@usp.br 


\section{Tuberculose: limites e potencialidades do tratamento supervisionado}

Objetivou-se analisar potencialidades e limites da estratégia do tratamento supervisionado (DOTS) para a tuberculose, sob a percepção de usuários em tratamento e de trabalhadores de saúde de uma supervisão técnica de saúde do município de São Paulo. Entrevistaram-se 4 usuários e 17 profissionais de saúde de nove unidades básicas de saúde, entre abril e junho de 2006, após consentimento livre e esclarecido. Os depoimentos foram decodificados segundo a técnica de análise de discurso. Adotou-se a teoria da determinação social do processo saúde/doença como referencial teórico. Foram potencialidades: criação de vínculo entre profissional/usuário e incentivos ao tratamento, o que favorece a adesão. Foram limites: restrito envolvimento dos profissionais no DOTS e conciliar horário de trabalho do usuário com a supervisão. Reitera-se que a adesão ao tratamento transcende o âmbito biológico, sendo fundamental que os trabalhadores de saúde reconheçam os usuários como portadores de necessidades, não se restringindo apenas à supervisão da tomada de medicamentos.

Descritores: Tuberculose; Terapia Diretamente Observada; Cooperação do Paciente; Enfermagem.

\section{Tuberculosis: límites y potencialidades del tratamiento supervisado}

Se objetivó analizar potencialidades y límites de la estrategia del Tratamiento Supervisado (DOTS) para la tuberculosis bajo la percepción de los usuarios en tratamiento y de los trabajadores de la salud de una Supervisión Técnica de Salud del Municipio de Sao Paulo. Se entrevistaron 4 usuarios y 17 profesionales de salud de nueve Unidades Básicas de Salud, entre abril y junio de 2006, después del consentimiento libre e informado. Las declaraciones fueron decodificadas según la técnica de análisis de discurso. Como marco teórico se adoptó la Teoría de la Determinación Social del Proceso Salud-Enfermedad. Las potencialidades encontradas fueron la creación de vínculo entre profesional/usuario y los incentivos al tratamiento, los que favorece la adhesión. Los límites fueron el reducido envolvimiento de los profesionales en el DOTS y el conciliar el horario de trabajo del usuario con la supervisión. Se reitera que la adhesión al tratamiento transciende el ámbito biológico, siendo fundamental que los trabajadores de la salud reconozcan a los usuarios como portadores de necesidades, que no se restringen a la supervisión de la ingesta de los medicamentos.

Descriptores: Tuberculosis; Terapia por Observación Directa; Cooperación del Paciente; Enfermería.

\section{Introduction}

This study is part of a line of research that investigates the analytical category adherence. It is relevant because it addresses the part of the study ${ }^{(1)}$ that conceives of adherence to DOTS for tuberculosis (TB) control as a dimension that goes beyond clinical and biological aspects, moving from multi-factors of the health-disease continuum to its social determination.

The epidemiological importance of TB is unquestionable. According to the World Health Organization (WHO), there were 13.7 million individuals with TB in 2007, worldwide. Brazil ranks $14^{\text {th }}$ among the 22 countries that concentrate $80 \%$ of cases, with about 114,000 individuals $^{(2)}$.

WHO declared TB as a state of emergency in 1993 and recommended that countries adopt the DOTS strategy to improve TB control and ensure the achievement of established goals for the success of control $(85 \%)$, case detection $(70 \%)$ and the reduction of treatment abandonment(3). The implementation of DOTS in Brazil in 1997 improved the rate of TB cure 
and reduced treatment abandonment and costs, when compared to the self-administered treatment ${ }^{(4-5)}$. DOTS was implemented in the following year in the state of São Paulo and from then to 2004, TB coverage increased in $69 \%$ of the 36 priority cities $^{(3)}$.

However, it is evident that such success is not homogeneous. In the city of São Paulo for instance, DOTS coverage achieved $50 \%$ in 2008 for active tuberculosis, but coverage was lower for sub-groups: $45.8 \%$ for those without fixed residence, $21.4 \%$ for inmates, and $22.8 \%$ for HIV patients ${ }^{(6)}$. The concentration of TB is greater in regions where there is social exclusion, in addition to a greater incidence in groups living in vulnerable contexts, thus the following aspects represent a challenge: TB/ HIV co-infection and multi-resistance to drugs due to inappropriate treatment and treatment abandonment.

DOTS has the potential to improve TB control, though problems putting it into operation hinder the achievement of goals. In this context, this study sought to understand how the strategy is implemented in Technical Health Supervision in Itaim Paulista in the east region of São Paulo, SP, Brazil, which has an important incidence of TB. The hypothesis that DOTS has strengths that favor treatment adherence but also limitations that can contribute to abandonment was considered. Abandonment occurs when greater importance is given to the supervision of medication taken instead of acknowledging the individuals' health needs.

\section{Objectives}

To identify the strengths and limitations regarding DOTS faced in the Technical Health Supervision in Itaim Paulista, São Paulo, SP, Brazil from the perspective of healthcare providers acting in TB control in Primary Care Units (PCU) in the region and from the perspective of individuals under treatment, as well as propose alternatives to improve its operation.

\section{Methods}

This qualitative study was conducted in nine of the 14 PCUs that included the Technical Health Supervision in Itaim Paulista, where the coverage of DOTS was $100 \%$. Three PCUs were excluded because there were no DOTS patients and another two due to the impossibility of rescheduling interviews. There were initially 50 total DOTS patients who, after exclusions, totaled 39. The study is part of a matrix-project, conducted in five regions of the city of São Paulo.

Healthcare providers and patients undergoing treatment were the subjects of this study. After authorization from the Health Department of São Paulo and from the Technical Health Supervision in Itaim Paulista was obtained, healthcare providers who supervised or coordinated DOTS in PCUs were contacted by phone and invited to participate in the study: 17 individuals composed the sample. Healthcare providers were then asked to indicate and invite patients, 18 years old or older, undergoing treatment to participate in the study; four individuals consented to participate.

We sought to ensure the participation of at least one patient per PCU. The number of how many would participate was not previously defined but determined by data saturation based on the representativeness and quality of testimonies collected during interviews more so than by quantity(7). Saturation was achieved when the representation of professionals concerning the limitations and strengths of DOTS became redundant. There was closure due to exhaustion in relation to patients because all those available (who consented to participate) were included in the study ${ }^{(7)}$.

After participants signed free and informed consent forms, interviews were conducted between April and June 2006 in the PCU itself where the participants' privacy was ensured. Two semi-structured interview scripts, which were tested in a previous study ${ }^{(1)}$, were used: one for the healthcare providers and another for patients. The questions addressed the characterization of the participants and their perceptions concerning: TB, difficulties and strengths of DOTS, and the determinants of treatment adherence/abandonment. Interviews were recorded and transcribed.

For the material empirical analysis, the TextGeneration and Meaning-Text Theory, which allows one to understand thematic phrases, was used(8). This process revealed the themes that constitute the perceptions of the study's participants concerning the main questions: 'TB', 'Impact of the disease on the lives of patients'; 'DOTS' and 'Treatment adherence'. The discussion was based on the Social Determination Theory of the Health-Disease Process. Hence, the interpretation of perceptions was based on the historical view of the health-disease continuum that conceives of human life as non-static, of the perceptions of the individuals as arising from the status they occupy in society and the way they live, and biological processes as being part of life in society. Therefore, health and disease are taken as part of a greater whole: life ${ }^{(9)}$.

The project was approved by the Ethics Research Committee at the Health Department in the city of São Paulo (Protocol No. 092/05). 


\section{Results}

\section{Participants}

Two patients were female and two male with an average age of 45 years old; they lived with their family members. They had studied 7.7 years on average and their mothers studied 3.7 years on average. One reported Pulmonary TB, one ocular TB and two did not know what type of disease they had. Three were undergoing the treatment for the first time and one had undergone treatment for the first time 13 years ago; three were in the third month of treatment and one in the fourth month. In relation to occupation, one was formally employed, one had temporary jobs, and the others were unemployed. All reported depending on their families for financial support. Patients and healthcare providers agreed on the place where supervision of medication taken would be performed: one was supervised at home and the other three at the PCU.

The healthcare providers included: seven nurses, four nursing auxiliaries and one nursing technician, in addition to five community health agents; their average age was 36.9 years old and they had provided care to TB patients for an average of 5.9 years.

\section{Participants' perceptions}

Figures 1 and 2 show the synthesis of perceptions of patients and professionals, respectively, in relation to category analysis: (Perception of) 'Tuberculosis'; 'Impact of the disease on the lives of patients'; 'DOTS': and 'Treatment adherence'.

\begin{tabular}{|l|l|}
\hline \multicolumn{1}{|c|}{ Category } & \multicolumn{1}{c|}{ Perceptions } \\
\hline Tuberculosis & Disease that carries a stigma, is dangerous, causes physical and mental pain, and is compared to AIDS. \\
\hline $\begin{array}{l}\text { Impact on the } \\
\text { patients' lives }\end{array}$ & $\begin{array}{l}\text { It harms daily life due to prejudice, rejection, causing isolation from society and family; leads individuals to fear transmitting the } \\
\text { disease to close people, linked to a feeling of uselessness and financial dependency due to the need to stop working. Changes } \\
\text { daily routine due to the fixed medication and meals schedule; imposes some restrictions such as alcohol consumption. }\end{array}$ \\
\hline DOTS & $\begin{array}{l}\text { Positive aspects: improves signs and symptoms, individuals receive snacks and food basket, it is easy to schedule consultations, } \\
\text { and PCU provides good care. } \\
\text { Negative aspects: having to abandon work due to need to go to the PCU to take medication. } \\
\text { For the majority, supervision was something normal; a time when they felt cared for receiving guidance concerning the treatment. } \\
\text { For others, it was related to shame, embarrassment, and the feeling they were not trustworthy before healthcare providers. }\end{array}$ \\
\hline $\begin{array}{l}\text { Treatment } \\
\text { adherence }\end{array}$ & $\begin{array}{l}\text { It is a result of one's desire to improve physical condition and resume activities and life plans set aside because of the disease } \\
\text { and also of the encouragement provided by family and the providers at the PCU. On the other hand, being unable to stop } \\
\text { drinking and smoking contributes to treatment abandonment. }\end{array}$ \\
\hline
\end{tabular}

Figure 1 - Perceptions of patients undergoing DOTS according to the categories of analysis. São Paulo, Brazil, 2006

\begin{tabular}{|c|c|}
\hline Category & Perceptions \\
\hline Tuberculosis & $\begin{array}{l}\text { It generates stigma and prejudice. It is a bad thing, an insidious disease because symptoms improve and lead patients } \\
\text { to believe they are cured. It is related to poverty, unemployment, and food deficiency. Those who are uninformed fear the } \\
\text { disease, which leads to prejudice. }\end{array}$ \\
\hline $\begin{array}{l}\text { Impact of the } \\
\text { disease on the } \\
\text { patients' lives }\end{array}$ & $\begin{array}{l}\text { It causes shock, surprise and feeling one is doomed to death. Causes patients undergoing treatment to become concerned, } \\
\text { feel anguished, depressed, discouraged, without hope that they will ever return to the condition they once had, and they } \\
\text { also feel isolated even from family, given the fear of prejudice and of transmitting the disease. }\end{array}$ \\
\hline DOTS & $\begin{array}{l}\text { Some feel embarrassed due to the supervision and others feel cared for and even more committed to the treatment. The } \\
\text { professionals are the most important elements in DOTS implementation because patients become vulnerable. Adherence is } \\
\text { controlled through verification of the empty pallet of drugs. } \\
\text { Strengths: incentives, family support, the work of community health agents, establishment of bonds with patients and } \\
\text { the acknowledgement of their singularity and health needs. Limitations: insufficient time and number of professionals; } \\
\text { patients' lack of confidence in the treatment; irregular supply of incentives; difficult communication between PCU and health } \\
\text { supervision; difficulty reconciling supervision and the patients' need to work; lack of preparedness; lack of interest and } \\
\text { motivation by the part of professionals. }\end{array}$ \\
\hline $\begin{array}{l}\text { Treatment } \\
\text { adherence }\end{array}$ & $\begin{array}{l}\text { It is related to: desire to be cured and able to resume plans; guidance; bonds; professionals' commitment; supply of } \\
\text { food basket; care that takes into account the patients' cultural and social dimensions; side effects; quantity of pills; } \\
\text { improvement of signs and symptoms; deficient knowledge concerning TB; need to work; alcohol consumption, smoking } \\
\text { and the use of illegal drugs; prolonged treatment; desire to keep receiving sickness benefit; impossibility of complying with } \\
\text { guidance provided concerning eating due to a poor financial situation; lack of family support; lack of desire to live. Alcohol } \\
\text { consumption is tolerated while seeking adherence. }\end{array}$ \\
\hline
\end{tabular}

Figure 2 - Perceptions of health professionals according to the categories of analysis. São Paulo, Brazil, 2006 


\section{Discussion}

Even though the number of interviewed patients is very restricted, their profile is similar to that found in other studies $^{(1,4,10-14)}$ : the disease affects individuals mainly during their productive time of life; they require financial support from their families; they have a poor level of employment or unemployment. The fact that patients have few years of education, a little more than their mothers, may be evidence for the historical character of social exclusion. It is a fact that TB is associated with the way society is organized and the status people occupy in it ${ }^{(1,14)}$. Such a profile reveals vulnerability, expressed in these individuals' poor living and working conditions, which in turn interferes in their access to resources. Included in those resources are health resources and information(15), which becomes a limitation in DOTS because individuals may distance themselves from the health service and hinder treatment ${ }^{(14)}$.

The analysis of the reports showed that TB, according to patients and professionals, leads to stigma, as indicated by other studies ${ }^{(10,13-14,16)}$. Disease brings physical and mental suffering, negatively impacts the lives of patients, forces them to leave their jobs, which are a source of income and which represent independence. A lack of independence is an obstacle to overcoming the situation of exclusion. It generates guilt, fear of prejudice and of transmitting the disease to others, a lack of the desire to live, and may be the cause of family estrangement. TB seems to be strongly associated with patients' poor self-esteem ${ }^{(10,13,16)}$, which reveals its complex character, requiring knowledge and sensitivity on the part of healthcare providers to implement care that goes beyond the biological sphere to include social issues implicated in the illness.

According to the reports, even though DOTS is effective, it is difficult and laborious. The positive aspects indentified in the 'DOTS' category also appear in the category 'Treatment adherence' as aspects that favor it.

The professionals identified DOTS as being a strength, helping patients feel more committed to their treatment(17-18), which meets the strategy's guidelines that recommends sharing responsibility between professionals and patients to achieve treatment success $^{(19)}$. The patients participated in determining the frequency and place where DOTS supervision would be carried out, showing that some needs are taken into account, which is essential to the issue of adherence ${ }^{(14,17)}$.

Yet, healthcare providers feel they are the ones most responsible for the treatment, since patients become vulnerable given TB, and adopt postures that are related to asymmetrical power (such as requiring the medication pallet to be empty), which does not contribute to strengthening the patients' autonomy, citizenship, or empowerment ${ }^{(20)}$, which is expected in health care. Hence, solidarity should be included in the care process, though solidarity should not be replaced by compassion, because the latter leads one to silence, gives no opportunity to voice one's needs, and therefore encourages submission ${ }^{(1)}$, which is often observed in health services.

The presence of community health agents was considered to be a strength because these are closer to the context of patients. Because these agents grasp the complexity of the disease in their context, they are able to support patients and contribute to treatment adherence ${ }^{(14,17)}$. Healthcare providers highlight that the support of family members is a positive aspect of DOTS because it avoids patient isolation. Both professionals and patients reported that family support contributes to treatment adherence. However, interviewees experienced estrangement from family members. In fact, being cared for, and being supported in technical, emotional and financial terms when facing a stigmatizing disease is reflected in the desire to be cured ${ }^{(1,5)}$.

According to patients, the main strength of DOTS and the encouragement of treatment adherence is attaining a cure and resuming previous activities, especially work and social life, in particular with family members. The perception that incapacity is over brings back lost dignity in a society that values individuals who are included in the process of production, even if they are being exploited, as occurs in most cases. A cure is also longed for by family members, who may have their income diminished during the treatment ${ }^{(21)}$.

According to the professionals and corroborated by literature, the improvement of symptoms is an aspect that contributes to non-adherence to DOTS because patients may think they are healed when their physical condition improves and abandon treatment ${ }^{(12)}$. This study's patients who were at least in the third month of treatment said that even though it was difficult to deal with the TB symptoms and the medications' side effects, they did not consider abandoning their treatment because they knew that only the full treatment ensures a cure. Hence, actions aimed to guide patients, their families and the community are essential to clarify for patients that the improvement of symptoms does not 
mean a cure and that abandonment may lead one to develop resistance to the medication.

The fact that patients considered receiving snacks, having good care and ease in scheduling consultations as strengths of DOTS indicates their level of social exclusion and that there are failures in access to the health system since one of the foundations of Primary Care is that it is the main entrance to the Single Health System (SUS) (22).

According to patients and healthcare providers, the establishment of bonds within DOTS is the principle that guides Primary Care ${ }^{(22)}$ and can be seen in this study as a relationship of trust and friendship established between professionals and patients over the course of treatment. It results from daily contact that allows professionals to perceive patients' needs other than those related to TB, allowing patients to share their doubts, problems and strengthen themselves in the face of their illness ${ }^{(1,13,17)}$.

Hence, this study points to the importance of professionals in listening to patient demands. Unfortunately, in the context in which these individuals live, permeated as it is with exclusion, feeling cared for and welcomed is not common. However, such actions should be valued and practiced by healthcare providers because they contribute to the establishment of bonds, help patients to acquire a feeling of belonging to society and better cope with daily life, as identified in other studies $^{(1,14)}$. Such actions can also ensure the exercise of rights and citizenship, which is oftentimes absent in the lives of TB patients ${ }^{(1,14)}$. DOTS enables inclusion and promotes the exchange of experiences and needs, which helps patients to recover their identity, even though it does not replace the necessary empowerment of people in the exercise of citizenship ${ }^{(1)}$.

The supervision of taking medication is perceived as both a strength and a limitation, as observed in the literature ${ }^{(1,14)}$. This study revealed that such an act is not restricted to observation, it is also a moment to care and in which a patient feels cared for. Most of the patients reported they did not feel bothered by observation and even liked it, because it represented an opportunity to exchange and share information and create bonds. Hence, it does not hurt one's rights to freedom and autonomy. On the other hand, a smaller proportion of people also felt embarrassed during supervision because of the feeling of disbelief it causes. Embarrassment can be overcome as professionals share with patients the guidelines that ground DOTS and highlight the importance of supervision to protect both the individual and the collective.
Both healthcare providers and patients consider the treatment's incentives (snack and food basket) positive aspects of DOTS that contribute to adherence. Such a fact may be related to the socio economic situation of patients. The sickness benefit, a resource aimed to help patient recovery, was indicated as an element that can limit treatment adherence. The reason is that patients may prolong their treatment so they continue receiving the benefit. As previously mentioned, all the study's patients depended on the financial help of family members. The incentives were important in constituting nutritional support and complementing family income. On the other hand, even though receiving snacks and food baskets contributed to adherence, the irregular supply of such incentives weakened the bond established between professionals and patients ${ }^{(1,13-14,17)}$ as the professionals often mention the incentive but its supply does not directly depend on them.

In relation to the negative aspects, reconciling DOTS and a paid job was seen by both groups as a limitation. Professionals should be flexible in relation to the supervision schedule, given the importance of patients keeping their jobs, seeking to keep a harmonious dynamic with patients' work activities ${ }^{(14,17,23)}$. Side effects (nausea, vomiting, anxiety), which have repercussions for treatment adherence, should be analyzed by healthcare providers because they can be resolved in the $\mathrm{PCU}^{(24)}$ and is the role of providers to have knowledge and intervene in these cases. One of the limiting aspects of DOTS, mentioned only by professionals, was the quantity of pills patients have to take: such a situation can be overcome with the combined fixed dose, adopted in Brazil since 2009(24).

Still discussing the difficulties faced with DOTS, professionals report having to deal with managerial problems and service organization (reference and counter-reference, delay in the supply of incentives and the results of exams, poor communication between the PCU and the Health Supervision). The managerial activities of the TB Control Program are implemented through city coordination in a centralized manner(5). Thus, there is a need for cooperation between central coordination and the PCUs, since the lack of such cooperation may harm the motivation of professionals, the credibility of PCUs before patients and hinder the flow of information concerning a disease, all of which are necessary for planning control actions.

Other negative aspects identified by healthcare providers were a lack of preparedness and interest on the part of their peers in working within DOTS, insufficient 
time to supervise medication taken- it competes with the remaining routine activities within the PCUand an insufficient number of employees in PCUs. All these contribute to non-adherence to treatment. These are important elements because they determine the quality of care and interaction between professionals and patients and influence the establishment of bonds $^{(12-13,16,25)}$. Health providers suggest that workers from different PCUs meet and discuss cases. They also recommend the implementation of training programs compatible with the possibilities of operation in the PCUs' region. Additionally, it is important to mention that continuous education programs can contribute to the improvement of professionals, so they feel encouraged to practice health interventions and cope with difficulties faced given the lack of valorization of the work in health. Even though not justified, the inappropriate postures of healthcare providers resulting from low wages, a stressful work process, and poor working conditions reflect on the quality of care ${ }^{(1)}$.

In relation to DOTS adherence, many of the aspects discussed in the previous categories also determine DOTS adherence. According to patients, in addition to those aspects already mentioned, non-adherence is also related to being unable to quite smoking and drinking alcohol, even considering that such practices negatively affect the therapeutic process; these limitations are taken into account in the recommendations of the Ministry of Health ${ }^{(24)}$. Given this situation, some providers, in accordance with the recommendation of the tuberculosis control program, reported instructing patients to take the medication even if consuming alcohol. Providers also assert that the use of illegal drugs is a limitation of DOTS. Considering how harmful these substances are, healthcare providers should talk to patients and seek to understand them and also identify their needs and support them. It reveals that cooperation among sectors is important(23), especially with services and associations dedicated to treat drug addiction, smoking and alcoholism, in addition to the community and patients' families ${ }^{(12-14)}$.

According to professionals, the inability of patients to comply with guidance (e.g. regarding appropriate eating) due to their situation of exclusion is also unfavorable to adherence. They also relate DOTS adherence to the representations, beliefs, values and knowledge of patients, families and community concerning TB, which is also in agreement with findings of other studies ${ }^{(12,17)}$. Even though this perception enlarges the restricted view of DOTS, that the observation of medication taken is the only element for treatment success, there is a perception of its multi-factor characteristic.

The multifactor characteristic of conditions causing TB became evident in this study, because the characteristics indicate that the sum of elements concerning life and work positively or negatively impact DOTS implementation. Such elements are dissociated from the way society is structured, and its determinations are not considered part of a process. It is evidence for the supremacy of the model supported by classical epidemiology, which usually is the axis of teaching in the health field, with repercussions for the way workers see reality and therefore in the way they intervene in the health-disease continuum.

\section{Final considerations}

This study showed the importance of considering TB as a disease that goes beyond the biological sphere because it is associated with the individuals' living and working conditions. It also showed the important responsibility of professionals working with DOTS. Not only do they need to have technical skills, competencies, and knowledge, but also managerial and relationship skills and an integral and dynamic view of world. These should be reflected in their actions, as they need to consider TB to be a process determined by the way society is structured.

The challenge imposed by TB both for the political and care delivery spheres is to take into account the context in which patients live in order to achieve treatment success through the offering of resources that facilitate this process. Hence, inter-sector actions that seem to depart from the "health" scope, and which are seldom practiced, are essential to promoting the participation of society and the establishment of bonds, and are part of SUS guidelines so that it functions with the required quality care.

Even if the refusal of some patients was a limitation imposed on this study, these findings point to some possibilities to improve DOTS, among which are: promote the discussion concerning TB in the community; promote the exchange of experiences among DOTS patients; improve the qualification of healthcare providers in relation to the establishment of bonds; improve the communication between PCUs and the region's health coordination; and establish communication with organizations and projects addressing social inclusion.

Achieving TB control implies considering the treatment as something dynamic that goes beyond 
individual aspects. It implies acknowledging that the disease does not emerge as a result of a positive sputum smear, but from the conditions in which patients live. Nursing can contribute given its important participation in the routine practice of the health services.

\section{References}

1. Bertolozzi MR. A adesão ao tratamento da TB na perspectiva da estratégia do Tratamento Diretamente Observado (DOTS) no Município de São Paulo - SP [tese de livre docência]. São Paulo (SP): Escola de Enfermagem da Universidade de São Paulo; 2005. 230 p.

2. World Health Organization. Global Tuberculosis Control: epidemiology, strategy, financing: WHO report 2009. Geneva: WHO; 2009. 304 p.

3. Villa TCS, Assis EG, Oliveira MF, Arcênio RA, Gonzáles RIC, Palha PF. Cobertura do tratamento diretamente supervisionado (DOTS) da TB no Estado de São Paulo (1998-2004). Rev Esc Enferm USP. 2008;42(1):98-104.

4. Falcão $A B$. Estudo Comparativo do tratamento supervisionado da tuberculose com o auto-administrado. Bol Pneumol Sanit. 2006;14(1):21-5.

5. Ruffino Netto A, Villa TCS, organizadores. TB: Implantação do DOTS em algumas regiões do Brasil. Histórico e Peculiaridades. Ribeirão Preto: Wdesign e Associados; 2006. 210 p.

6. Coordenadoria de Vigilância em Saúde da Secretaria Municipal de Saúde da Prefeitura do Município de São Paulo (BR). Boletim TB Cidade de São Paulo. São Paulo; 2009. $10 \mathrm{p}$.

7. Fontanella BJB, Ricas J, Turato ER. Amostragem por saturação em pesquisas qualitativas em saúde: contribuições teóricas. Cad Saude Publica. 2008;24(1):17-27.

8. Fiorin JL. Elementos de análise do discurso. São Paulo: EDUSP; 1989. 93 p.

9. Fonseca RMGS, Bertolozzi MR. A epidemiologia Social e a assistência à saúde da população. In: Egry $E Y$, Antunes MJM, Chompre RR, Almeida MCP, Silva IA da. A Classificação das Práticas de Enfermagem em Saúde Coletiva: a experiência brasileira. Série Didática de Enfermagem no SUS 1999;1(1):34-45.

10. Lima MB, Mello DA, Morais AP, Silva WC. Estudo de casos sobre o abandono do tratamento da tuberculose: avaliação do atendimento, percepção e conhecimentos sobre a doença na perspectiva dos clientes (Fortaleza, Ceará, Brasil). Cad Saude Publica. 2001;17(4):877-85.
11. Speciale C. Significados do Tratamento Diretamente Supervisionado ("DOTS") para pacientes com tuberculose do Programa de Saúde da Família da Supervisão Técnica de Vila Prudente/ Sapopemba, São Paulo - SP. [dissertação de mestrado]. São Paulo (SP): Escola de Enfermagem da Universidade de São Paulo; 2007. 99 p.

12. Paixão LMM, Gontijo ED. Perfil de casos de tuberculose notificados e fatores associados ao abandono, Belo Horizonte, MG. Rev Saude Publica. 2007;41(2):205-13. 13. Terra MF. O Tratamento Diretamente Supervisionado ("DOTS") como estratégia para a adesão ao tratamento da tuberculose: significados segundo profissionais de saúde da supervisão técnica de saúde do Butantã, São Paulo SP. [dissertação de mestrado]. São Paulo (SP): Escola de Enfermagem da Universidade de São Paulo; 2007.

14. Queiroz EM, Bertolozzi MR. TB: tratamento supervisionado nas Coordenadorias de Saúde Norte, Oeste e Leste do Município de São Paulo. Rev Esc Enferm USP. 2010;44(2):453-61.

15. Ayres JRCM, França-Júnior I, Calazans GJ, SalettiFilho HC. O conceito de vulnerabilidade e as práticas de saúde: novas perspectivas e desafios. In: Czeresnia D, Freitas CM, organizadores. Promoção da saúde: conceitos, reflexões, tendências. Rio de Janeiro: Fiocruz; 2003. $176 \mathrm{p}$.

16. Lima AL, Souza FBA, Ferreira GL. Tubérculos: atitudes do cliente frente à doença. Bol Pneumol Sanit. 2005;13(2):83-90.

17. Terra F, Bertolozzi MR. Tratamento diretamente supervisionado (DOTS) contribui para a adesão ao tratamento da TB? Rev. Latino-Am. Enfermagem. 2008;16(4):659-64.

18. Oliveira SAC, Ruffino-Netto A, Villa TCS, Vendramini SHF, Andrare RLP, Scatena LM. Health services in tuberculosis control: family focus and community orientation. Rev. Latino-Am. Enfermagem. 2009;17(3):361-7.

19. Secretaria de Estado da Saúde de São Paulo (BR). Centro de Vigilância Epidemiológica. Divisão de Tuberculose. Manual do Tratamento Supervisionado. São Paulo: CVE; 2004.

20. Kleba ME, Wendausen A. Empoderamento: processo de fortalecimento dos sujeitos nos espaços de participação social e democratização política. Saude Soc. $2009 ; 18(4): 733-43$. 
21. Costa JG, Santos AC, Rodrigues LC, Barreto ML, Roberts JA. Tuberculose em Salvador: custos para o sistema de saúde e para famílias. Rev Saude Publica. 2005;39(1):122-8.

22. Ministério da Saúde (BR). Secretaria de Atenção Básica. Política Nacional de Atenção Básica Brasil. Brasília: Ministério da Saúde; 2006. 60 p.

23. Paz EPA, Sá AMM. The daily routine of patients in tuberculosis treatment in basic health care units: a phenomenological approach. Rev. Latino-Am. Enfermagem. 2009;17(2): 180-6.

24. Ministério da Saúde (BR). Secretaria de Vigilância em Saúde. Programa Nacional de Controle da Tuberculose. Manual de Recomendações para o Controle da Tuberculose no Brasil. [acesso 08 set 2010]. Disponível em: http://portal.saude.gov.br/portal/arquivos/pdf/ manual_de_recomendacoes_controle_tb_novo.pdf

25. Bertazone EC, Gir E, Hayashida M. Situações vivenciadas pelos trabalhadores de enfermagem na assistência ao portador de tuberculose pulmonar. Rev. Latino-Am. Enfermagem. 2005;13(3):374-81. 